\title{
CONOR - COhort NORway: historie, formål og potensiale
}

\author{
Per Magnus ${ }^{1}$, Egil Arnesen ${ }^{2}$, Jostein Holmen ${ }^{3}$, Camilla Stoltenberg ${ }^{1}$, \\ Anne Johanne Søgaard ${ }^{1}$ og Grethe S. Tell ${ }^{4}$ \\ ${ }^{I}$ Divisjon for epidemiologi, Nasjonalt folkehelseinstitutt, Oslo \\ ${ }^{2}$ Institutt for samfunnsmedisin, Universitetet i Tromsø \\ ${ }^{3}$ HUNT forskningssenter, Institutt for samfunnsmedisin, NTNU, Verdal \\ ${ }^{4}$ Institutt for samfunnsmedisinske fag, Universitetet $i$ Bergen \\ Korrespondanse: Per Magnus, Nasjonalt folkehelseinstitutt, Postboks 4404 Nydalen, 0403 Oslo \\ Telefon: 23408211 Telefax: 23408252 E-post: per.magnus@fhi.no
}

\begin{abstract}
SAMMENDRAG
CONOR (COhort NORway) ble startet for å finne årsaker til sjeldne sykdommer. Tanken er å samle inn eksponeringsdata flere år før sykdom utvikles. Eksponeringsdata hentes dels fra spørreskjemaer, dels fra analyser av blodprøver og dels fra informasjon som kobles til personfilen fra andre kilder. Informasjon om sykdom hentes fra koblinger til sykdoms- og dødsårsaksregistre og fra selvrapporterte spørreskjemaopplysninger. Når blodprøver skal studeres benyttes nøstede case-kontrollundersøkelser. Prosjektet er en nasjonal ressurs, og skal benyttes når problemstillingene ikke kan studeres godt nok innen en enkelt regional helseundersøkelse. CONOR inngår i BIOHEALTH NORWAY som er en biobankplattform i den nasjonale satsingen i funksjonell genomforskning (FUGE). Artikkelen gir historikk og fremtidsperspektiver for CONOR.
\end{abstract}

\section{INNLEDNING}

Hensikten med artikkelen er å gi begrunnelsen for CONOR, en kort historikk og en diskusjon av hva vi kan bruke CONOR til i fremtiden.

\section{HVA ER CONOR?}

CONOR er en forkortelse for COhort NORway. Det er et forskningssamarbeid mellom epidemiologiske miljøer i Norge rundt en kohort som per september 2003 består av 167000 voksne personer med standardiserte opplysninger om eksponeringer og helseforhold og med nedfrosne blodprøver. Målet er å rekruttere minst 200000 personer og å følge disse personene mot sykdom og død gjennom koblinger til helseregistre og dødsårsaksregisteret, eventuelt også ved gjentatt deltakelse i befolkningsundersøkelser. Mer informasjon finnes på CONORs hjemmeside (1). I en annen artikkel i dette nummeret gir Engeland og Søgaard (2) en oversikt over innholdet i denne forskningsdatabanken.

\section{HVORFOR BLE CONOR TIL?}

Bakgrunnen er manglende årsakskunnskap om alvorlige sykdommer. Etterkrigstidens epidemiologiske forskning hadde demonstrert hvor viktig kohortundersøkelser var for å finne sammenhenger mellom faktorer i levesett og miljø og utviklingen av enkelte kroniske sykdommer. Den britiske kohorten av leger som blant annet viste at røyking er årsak til lungekreft, og oppfølgingen av befolkningen i Framingham som har vært en hovedkilde til artikler om hjerte-/karsykdom var gode eksempler. Selv om randomiserte intervensjonsundersøkelser kan være et bedre design, vil slike undersøkelser være kostbare og ofte bare kunne svare på ett forskningsspørsmål av gangen. Ved å samle inn biologisk materiale og spørreskjemaundersøkelser og ha muligheten for å koble på eksponeringsopplysninger fra andre kilder, kan man i en norsk kohort ha en betydelig bredde i eksponeringer, og også kunne koble kohorten opp mot mange endepunkter. Dette gir opphav til en rekke problemstillinger. Ved å fordype seg i forskningsspørsmålene og gjerne supplere kohorten med ekstra datatilfang og validitetsunders $ø$ kelser vil norske epidemiologer kunne gjennomføre studier av høy vitenskapelig verdi.

Norsk epidemiologi fikk en vitamininnsprøytning på slutten av 1980-tallet gjennom daværende NAVFs (Norges allmennvitenskapelige forskningsråds) program for epidemiologi. På basis av en innstilling utarbeidet av en komite i 1986 under ledelse av Fredrik Mellbye bevilget NAVF fra årene 1987 og fremover omtrent 55 millioner kroner på å styrke epidemiologisk forskning (3). Programstyret for epidemiologisk forskning, ledet av Olav Helge Førde, gjennomførte mange av anbefalingene fra komiteen, for eksempel opprettingen av toppstillinger og mellomstillinger ved universitetene (4). Til sammen ble 33 doktorgradsstipendiater rekruttert gjennom programmet. Flere ganger ble mulighetene for å starte store kohortundersøkelser drøftet av programstyret. Man diskuterte både fødselskohorter og kohorter av voksne personer. For å integrere genetikk og miljøfaktorer utredet man muligheten for å opprette en DNA-bank som en del av en ko- 
hort (5). Forslaget i den utredningen var å ha 100000 tilfeldig uttrukne nordmenn $\mathrm{i}$ en kohort med standardiserte spørreskjemadata og blodprøver.

Etter at programperioden var ferdig, sto man igjen med en god ide om en kohort (6), men ingen organisasjon for å gjennomføre den. En realistisk vurdering av hva som var gjennomførbart og klokt å gjøre tilsa at man burde bygge på planlagte datainnsamlinger i de etablerte epidemiologiske forskningsmiljøene (på det daværende tidspunkt var det planlagt undersøkelser i Tromsø og Nord-Trøndelag), og danne en kohort på 200000 personer med utgangspunkt i regionale helseundersøkelser (7). Denne kohorten skal kunne kobles mot endepunktsregistre eller helsedata fra repeterte spørreskjemaundersøkelser slik at det ble mulig å gjøre nøstede case-kontroll-undersøkelser med analyser av biologisk materiale. En så stor kohort ville muliggjøre at relativt sjeldne sykdommer kunne studeres.

Det var møtevirksomhet mellom representanter fra de epidemiologiske miljøer ved universitetene og sentrale helseinstitusjoner (Statens helseundersøkelser (SHUS), Statens institutt for folkehelse, Kreftregisteret). Det ble enighet om å lage et felles basisdatasett fra spørreskjemaer, antropometriske målinger og enkelte målinger i serum og samtidig fryse ned blodprøver. CONOR ble dermed til et felles element i de regionale helseundersøkelsene som ble satt i gang utover 1990-tallet. Før den første regionale helseundersøkelsen var det hyppig møtevirksomhet for å bestemme innholdet i fellesspørsmålene. Slik det alltid er når en komite skal lage spørreskjemaer, ble det en del kompromisser og løsninger som ikke alle var like fornøyd med. Av praktiske og av og til tilsynelatende idiosynkratiske årsaker ble det noen mindre endringer i spørsmålene i de enkelte undersøkelsene. Disse endringene er det redegjort for på CONORs hjemmeside (1).

Datainnsamlingen startet i 1994-1995 i Tromsø, fortsatte med Nord-Trøndelag (1995-1997), Hordaland (1997-1999), Oslo (2000-2001), Hedmark og Oppland (2000-2001) og Troms og Finnmark (fra 2002). Det henvises til hjemmesidene for disse undersøkelsene (kan nås via (1)) for nærmere opplysninger om datainnsamlingsprosedyrer og problemstillinger. For å nå 200000 vil også andre befolkningsundersøkelser bli inkludert.

Opplegget for de enkelte regionale helseunders $\varnothing-$ kelsene ble bestemt av lokale styringsgrupper og datainnsamlingen ble gjennomført i samarbeid med Statens helseundersøkelser. De regionale undersøkelsene har som regel fordelt CONOR-spørsmålene på to skjemaer: et skjema 1 som deltakerne får tilsendt før de møter til undersøkelse, og et skjema 2 som de får med seg til utfylling etter at de har møtt. CONOR-spørsmålene dannet også mal for de etterfølgende 40-årsundersøkelsene som ble gjennomført av SHUS, men i de undersøkelsene ble det ikke tatt vare på blodprøver.

Tanken har vært at CONOR ikke skal utnyttes for problemstillinger som kan løses innen en region. CONOR kan sies å være en pragmatisk, dynamisk kohort $\mathrm{i}$ den forstand at stadig nye personer rekrutteres inn i kohorten uten andre inklusjons- eller eksklusjonskriterier enn de som er gitt ved samtykket og ved opplegget $\mathrm{i}$ de regionale undersøkelsene. Man måtte basere seg på den aldersfordeling som var valgt i de enkelte regionale undersøkelsene. Som vist av Engeland og Søgaard giR dette likevel en god aldersspredning (2). Både byer (Tromsø, Bergen, Oslo) og landdistrikter (Nord-Trøndelag, Hordaland, Oppland, Hedmark, Troms og Finnmark) er med. Det viktigste er at det er god spredning i verdier for eksponeringsfaktorene som studeres. Formålet er ikke å gi representative prevalensestimater for Norge, verken for eksponeringer eller sykdommer, men å beregne så riktig grad av assosiasjon mellom eksponeringer og helseutfall som mulig. Det vil si at man må ta hensyn til systematiske feilkilder som kan knyttes til seleksjonen, kvaliteten av informasjonen og problemene som kan knyttes til manglende kontroll for confoundere. Dette er spørsmål som må diskuteres $\mathrm{i}$ forhold til den enkelte problemstilling. Hvis seleksjonen til deltakelse er noenlunde ensartet $\mathrm{i}$ alle regioner, vil imidlertid sammenligninger av sykdomsforekomst i de ulike regionene være av stor interesse.

\section{STYRINGSGRUPPEN}

For å styre CONOR valgte det daværende Sosial- og helsedepartementet å opprette en styringsgruppe i 1994. Denne ble reoppnevnt i 1995. Det ble foretatt en personlig oppnevning. Professor Peter F. Hjort ble utnevnt til leder for styringsgruppen. Øvrige medlemmer var Egil Arnesen, Sissel Lyberg Beckmann, Kjell Bjartveit, Grete Botten, Jostein Holmen, Per Magnus og Leif Edvard Aarø. På slutten av 1995 ble Grethe S. Tell oppnevnt som medlem etter Aarø. Styringsgruppens opprinnelige mandat var å gi en oversikt over bakgrunnen for CONOR, samt konkretisere og beskrive innholdet i prosjektet. Dette ble gjort. Det var i perioden 1994-1996 atskillig diskusjon innad i styringsgruppen om hva CONORs profil skulle være. Hvor mye skulle man legge til rette for helsetilbud, helseinformasjon og helsetjenesteforskning i forbindelse med undersøkelsene? Et hovedproblem i 1994 var å argumentere for at blodprøver skulle fryses ned til senere bruk. Prosjektet ble diskutert på regjeringsnivå etter at daværende helseminister Werner Christie hadde innhentet detaljerte opplysninger om hensikten med blodprøvene. Regjeringen anbefalte at prosjektet ble gjennomført.

Styringsgruppen hadde ikke økonomiansvar eller personalansvar, men hadde som hovedoppgave å koordinere arbeidet og ta beslutninger om innholdet $i$ prosjektet. Med unntak av en bevilgning på kr 100000 og en mindre bevilgning til frysere har CONORs styringsgruppe ikke hatt egne midler til undersøkelsene. Midlene til gjennomføringen av prosjektet inngikk i tildelingen til Statens helseundersøkelser og ved at de regionale studiene skaffet egne midler. Styringsgrup- 
pen ble reoppnevnt i 1999. Da gikk Hjort, Bjartveit, Botten og Lyberg Beckmann ut av styringsgruppen, mens Yngve Haugstvedt, Anne Johanne Søgaard og Dag Thelle ble nye medlemmer. Per Magnus ble bedt om å være leder. SHUS fungerte som sekretariat for styringsgruppen, og nye befolkningsundersøkelser i Hedmark, Oppland, Troms og Finnmark gikk inn i CONOR. Fra 1. januar 2002 har helsedepartementet overført styringen av CONOR til Nasjonalt folkehelseinstitutt. CONOR forutsetter at de epidemiologiske miljøene som deltar, er enige om det videre samarbeid. Høsten 2003 vil mandatet og sammensetningen av CONORs styringsgruppe bli nærmere fastsatt, samtidig som en revidert protokoll blir lagt ut på hjemmesiden.

\section{BIOBANKENE OG RELASJONEN TIL FUGE}

Ikke minst på bakgrunn av usikkerheten omkring etikken ved nedfrysing av blodprøver, var det vanskelig å argumentere for store ressurser til biobanker på begynnelsen av 1990-tallet. Datatilsynet stilte også svært strenge krav til innsamlingen av blodprøver til biobanken i Nord-Trøndelag. Denne holdningen har endret seg betydelig, og innholdet i biobankene er i dag av mange betraktet som det mest verdifulle ved CONOR. Men vanskelighetene førte til at man i de første undersøkelsene frøs ned koagelrester i stedet for EDTAblod. Det var med nød og neppe man fant penger til frysere.

Utviklingen i molekylærbiologi har ført til en internasjonal satsing på såkalt funksjonell genomforskning. I Norge er dette uttrykt i den nasjonale FUGEsatsingen. Medlemmene av CONORs styringsgruppe sammen med ledelsen i Den norske mor og barn undersøkelsen foreslo i 2002 at det skulle dannes et nettverk av forskningsbiobanker i Norge (BIOHEALTH NORWAY) som skulle være en plattform for utnyttelse av biobankmateriale i funksjonell genomforskning. Dette gikk igjennom, og Norges forskningsråd har bevilget omtrent 50 millioner kroner til denne plattformen i årene 2002-2006. En vesentlig del av disse midlene vil bli brukt til å ekstrahere DNA fra fullblod og koagler, slik at genotyping blir mulig som ledd i årsaksforskningen.

\section{TilgJengelighet AV DATA}

CONOR er nå i den gledelige situasjon at det er mulig å begynne utnyttelsen av data. Det arbeides med å ferdigstille og kvalitetssikre en datafil som skal være tilgjengelig for tverrsnittsanalyser. Den vil senere bli koblet mot endepunktsregistre og kunne analyseres i forhold til persontid under risiko. Det er allerede gjort en kobling mot Medisinsk fødselsregister for å studere sammenhengen mellom risikofaktorer for hjerte-/karsykdom hos foreldre og uheldige svangerskapsutfall. For å få tilgang til data skal man skrive en kort prosjektbeskrivelse med problemstilling, en beskrivelse av utvalget og hvilke variable som skal benyttes $i$ analysen, samt fremdrifts- og publiseringsplan. Utleverte data vil være anonymiserte. Styringsgruppen vil prøve å koordinere forskningen, og oppfordre forskere med samme eller lignende problemstilling om å samarbeide. Utlevering av DNA eller serum vil kreve mer grundig avtale, siden det er snakk om begrensede mengder. Nærmere retningslinjer for tilgang til CONOR-data blir lagt ut på hjemmesiden i løpet av høsten 2003.

\section{FREMTIDSPERSPEKTIVER}

Kohortundersøkelser har ofte den egenskap at de blir mer verdt etter som tiden går (8). Antallet dødsfall og sykdomstilfeller øker. Heldigvis er spørreskjemadataene ikke forgjengelige. Problemet er å forvalte blodprøvene slik at de ikke ødes til unyttige problemstillinger eller til prosjekter med for lav styrke. Det har vært en eventyrlig utvikling i molekylær genetikk mens datainnsamlingen har pågått. I dag trengs ørsmå mengder DNA til omfattende genotypinger. Om noen år kan man kanskje beskrive den enkelte persons totale DNA-sekvens basert på et lite kvantum DNA. Da blir det ikke lenger nødvendig å ta vare på DNAet. Serumet vil degraderes over tid, og det er nødvendig å gjøre analyser for å finne ut hvilken kvalitet det er på målinger av proteiner og andre makromolekyler. Hvis det opprettes et forskningsregister i Norge med oversikt over alle slektskap, vil man kunne koble familietrær mot CONOR for å finne beslektede personer der man har biologisk materiale tilgjengelig. Dette kan ha stor betydning for å studere de enkelte geners betydning som sykdomsårsak. Det spesielt verdifulle med CONOR er muligheten til å forstå samspillet mellom miljøeksponeringer og gener, en kunnskap som i dag er sterkt etterspurt, og som kanskje er den eneste vei for å forstå årsakene til mange komplekse sykdommer. Det er å håpe at man om noen år vil kunne se tilbake på en serie publikasjoner med basis i CONOR, som forteller at man gjorde en riktig vurdering for 10-15 år siden når man begynte planleggingen.

\section{REFERANSER}

1. http://www.fhi.no/tema/conor

2. Engeland A, Søgaard AJ. CONOR (COhort NORway) - en oversikt over en unik forskningsdatabank. Norsk Epidemiologi 2003; 13 (1): 73-77.

3. Komiteinnstilling. Epidemiologisk forskning om sammenhengen mellom miljø og helse. Rådet for medisinsk forskning/Rådet for samfunnsvitenskapelig forskning, NAVF, Oslo, 1986. 
4. Norges forskningsråd. Epidemiologisk forskning om sammenhengen mellom miljø og helse. Rapport for perioden 1987-1992. Oslo, mai 1994.

5. Komiteinnstilling. Det forskningsmessige behov for etablering av en DNA-bank i Norge. Rådet for medisinsk forskning, Norges allmennvitenskapelige forskningråd, oslo, 1988.

6. Magnus P. CONOR - en forskningsidé under debatt. Norsk Epidemiologi 1992; 2 (2): 26.

7. Magnus P. CONOR - Hva skjer? Norsk Epidemiologi 1994; 4 (1): 64.

8. Grimes DA, Schultz KF. Cohort studies: marching towards outcomes. Lancet 2002; 359: 341-5. 